\title{
Iktiofauna air tawar Pulau Enggano, Indonesia
}

\author{
[Freshwater fish of Enggano Island, Indonesia] \\ Renny Kurnia Hadiaty ${ }^{\square}$ \& Sopian Sauri \\ ${ }^{1}$ Museum Zoologicum Bogoriense (MZB), Laboratorium Iktiologi, Bidang Zoologi, Pusat Penelitian Biologi \\ Lembaga Ilmu Pengetahuan Indonesia \\ Jl. Raya Bogor Km 46, Cibinong 16911
}

Diterima: 10 Juli 2017; Disetujui: 26 September 2017

\begin{abstract}
Abstrak
Pulau Enggano merupakan satu pulau terluar dari negara kepulauan, Indonesia. Survei ikan air tawar dilakukan di Pulau Enggano dengan tujuan untuk mendapatkan informasi iktiofauna yang ada di pulau ini. Koleksi sampel ikan dilakukan di 11 perairan tawar. Kami memperoleh 457 spesimen dari 28 spesies yang termasuk dalam 11 famili dan 3 ordo. Satu jenis diantaranya, Stiphodon sp. diduga merupakan jenis baru dan lima jenis lainnya perlu dikaji lebih lanjut untuk mengetahui status taksonominya. Semua spesimen hasil koleksi dideposit di Museum Zoologicum Bogoriense (MZB) dalam 77 nomor MZB. Diharapkan data iktiofauna pulau ini dapat digunakan sebagai dasar pertimbangan pemerintah daerah dalam pengelolaan sumber daya P. Enggano.
\end{abstract}

Kata penting: koleksi, spesimen, Stiphodon, Museum Zoologicum Bogoriense

\begin{abstract}
Enggano is an outer island of the archipelago country, Indonesia. A field survey of freshwater fish fauna conducted in Enggano island to get the information of the ichthyofauna of this island. The fish collected in 11 freshwaters. We got 457 fish specimens of 28 species in 11 families and three orders. One species, Stiphodon sp. suspected to be new to science and five species require further study to clarify their taxonomical status. All of the fish collected specimens deposited in 77 catalog numbers of Museum Zoologicum Bogoriense (MZB). The ichthyofauna of this island could be use as the basic data for the resource management of the Enggano island.
\end{abstract}

Key words: collection, specimens, Stiphodon, Museum Zoologicum Bogoriense

\section{Pendahuluan}

Indonesia merupakan negara kepulauan. $\mathrm{Pu}-$ lau yang berkoordinat dan terdaftar di Perserikatan Bangsa-bangsa (PBB) melalui United Nations Groups of Experts on Geographical Names (UNGEGN) berjumlah 13.466 pulau (BIG 2015). Jumlah ini dapat diperbaharui setiap tahunnya melalui badan tersebut. Selama ini masyarakat Indonesia berpendapat bahwa jumlah pulau di Indonesia berkisar 17000, hal ini disebabkan gosong (daratan pasir, geluh atau kerikil yang terbentuk akibat aliran air di perairan dangkal dan sempit) yang hanya muncul saat air laut surut juga dihitung sebagai pulau (BIG 2015). Badan Informasi Geospasial (BIG) merupakan

$\triangle$ Penulis korespondensi

Alamat surel: rkhadiaty@gmail.com
National Names Authority untuk Indonesia yang bertugas melaporkan data pulau bernama ke UNGEGN. Bersama dengan Kementerian Kelautan dan Perikanan, BIG melaporkan pada Konferensi ke 11 UNGEGN bulan Agustus 2017 bahwa di Indonesia ada 16.056 pulau (http: //news. kkp.go.id/ index.php/indonesia-laporkan16-056-pulau-bernama-ke-pbb/).

Pulau-pulau kecil terluar di Indonesia ada 111, yang ditetapkan dalam Surat Keputusan Presiden nomor 6 tahun 2017. Di Provinsi Bengkulu ada dua pulau terluar, yaitu Pulau (P.) Enggano dan P. Mega. Keanekaragaman ikan air tawar P. Enggano belum terungkap. Penelitian komunitas ikan karang di perairan P. Enggano yang telah dilakukan peneliti dari Pusat Penelitian Oseanografi-LIPI mencatat ada 187 jenis (Adrim 2007). 
Catatan tentang ikan air tawar di P. Enggano, ada dua spesies yang dilaporkan keberadaannya oleh Perugia pada tahun 1893, yaitu Gobius modigliani dan Eleotris squamifrons (Eschmeyer \& Fricke 2015). Spesimen kedua jenis tersebut disimpan di Museo Civico di Storia Naturale di Genova (MSNG) dengan nomor MSNG 12659 dan 12691. Namun saat ini keduanya merupakan sinonim dari jenis Acentrogobius janthinopterus dan Butis amboinensis.

Selama dua dasawarsa lalu, kegiatan penelitian di Pusat Penelitian Biologi dilakukan di pulau-pulau besar seperti Jawa, Sumatera, Kalimantan dan Sulawesi (Hadiaty 1996, 2001ab, 2003abc, 2005, 2007, 2011ab; Hadiaty 2012, Hadiaty \& Wirjoatmodjo 2003; Hadiaty \& Siebert 2003, Hadiaty \& Rachmatika 2003, Hadiaty et al. 2003, 2004, Hadiaty \& Sauri, 2014, Salas et al. 2005). Penelitian di pulau-pulau besar berhasil mendeskripsi 32 ikan jenis baru yang belum pernah diketahui sebelumnya (Hadiaty \& Siebert 1998, 2001; Hadiaty \& Kottelat 2009abc, 2010; Hoese et al. 2015, Keith et al. 2014ab, Larson et al. 2014, Ng et al. 2001ab, 2004; Ng \& Hadiaty 2005, 2008, 2009ab, 2011) serta satu genus dan jenis baru (Ng et al. 2015). Penelitian iktiofauna air tawar telah dilakukan pula di wilayah daratan Papua (Hadiaty 2008, 2009, Hadiaty et al. 2012). Dari penelitian di Papua diperoleh 25 ikan jenis baru (Graf et al. 2015, Hadiaty \& Allen 2011, Allen \& Hadiaty 2011, 2013, 2014; Allen et al. 2008, 2014, 2015bc).

Pada beberapa tahun terakhir kegiatan penelitian mulai beralih ke pulau-pulau kecil, diantaranya yaitu di Pulau (P.) Waigeo, P. Batanta, P. Muna, P. Halmahera, P. Bali, dan Kepulauan Aru. Di beberapa pulau kecil tersebut telah dideskripsikan 10 ikan jenis baru (Allen et al. 2015a, Nielsen et al. 2009, Parenti \& Hadiaty
2010, Hoese et al. 2017, Keith \& Hadiaty 2014, Keith et al. 2012).

Eksplorasi sumber daya hayati di P. Enggano dilakukan oleh para peneliti dari Pusat Penelitian Biologi, Kedeputian Ilmu Pengetahuan Hayati, Lembaga Ilmu Pengetahuan Indonesia pada bulan April-Mei 2015. Penelitian iktiofauna merupakan satu bagian dari kegiatan tersebut dan bertujuan untuk mengungkap keanekaragaman jenis ikan di pulau tersebut. Semua spesimen ikan hasil penelitian di P. Enggano ini dideposit di Museum Zoologicum Bogoriense (MZB). Diharapkan data iktiofauna P. Enggano ini menjadi dasar pertimbangan pemerintah daerah dalam pengelolaan sumber daya P. Enggano.

\section{Bahan dan metode}

Waktu dan lokasi

Penelitian dilakukan selama 20 hari, dari tanggal 16 April sampai 5 Mei 2015. Pemilihan lokasi penelitian mempertimbangkan keterwakilan tiga wilayah bentang alam P. Enggano, yaitu:

1. Wilayah barat, penelitian dilakukan di seputar Dusun Bendung, Desa Banjarsari. Di dusun ini ikan dikoleksi dari S. Kamayan, S. Kahabi, S. Paubah dan S. Kinono

2. Wilayah tengah, di sekitar kota Kecamatan Malakoni yaitu di S. Kipupu, S. Anno dan S. Paco

3. Wilayah timur, kegiatan penelitian dilakukan di Desa Kaana (S. Kikuba dan S. Apiko) dan Desa Kahyapu yaitu di S. Kahyapu, Alur dekat rumah mantan Kades.

Hampir semua perairan tersebut di atas mengalir ke arah utara dan satu alur sungai yang mengalir ke sisi timur. Penelitian tidak dilakukan di sungai ke arah selatan, karena faktor cuaca yang tidak bisa diprediksi di perairan yang mengalir ke Samudra Hindia tersebut. 
Pengambilan contoh ikan dilakukan di 11 lokasi perairan air tawar di P. Enggano, Kecamatan Enggano, Kabupaten Bengkulu Utara, Provinsi Bengkulu (Gambar 1) dengan rincian sebagai berikut:

1. Sungai Kamayan, $05^{\circ} 21^{\prime} 00.2^{\prime \prime} \mathrm{S}$; $102^{\circ} 10^{\prime} 46.4 " E$, Dusun (Dsn.) Bendung, Desa (Ds.) Banjarsari

2. Sungai Kahabi, $05^{\circ} 19^{\prime} 48.1^{\prime \prime} \mathrm{S}$; $102^{\circ} 10^{\prime} 54.6^{\prime E}$, Dsn. Bendung, Ds. Banjarsari

3. Sungai Paubah, anak S. Kahabi, 05²0'09.5" S; 102¹0'14.9"E, Dsn. Bendung, Ds. Banjarsari

4. Sungai Kinono, $05^{\circ} 19^{\prime} 49.4^{\prime \prime} \mathrm{S}$; $102^{\circ} 09^{\prime} 47.9^{\prime \prime E}$, Ds. Banjarsari
5. Sungai Kipupu, $05^{\circ} 19^{\prime} 48.1^{\prime \prime} \mathrm{S}$; $102^{\circ} 15^{\prime} 15.2^{\prime \prime E}$, Ds. Meok

6. Sungai Anno, $05^{\circ} 21^{\prime} 35.2^{\prime \prime} \mathrm{S} ; 102^{\circ} 16^{\prime} 59.9^{\prime \prime} \mathrm{E}$, Desa Malakoni

7. Sungai Paco, anak S.Kuala Kecil, $05^{\circ} 22^{\prime}$ 35.2" S; $102^{\circ} 18^{\prime} 11.05^{\prime \prime E}$, Ds. Malakoni

8. Sungai Kikuba, $05^{\circ} 23^{\prime}$ 04.6" S; $102^{\circ} 20^{\prime} 40.8^{\prime \prime E}$, Ds. Kaana

9. Sungai Apiko, 52 $23.308^{\prime} \mathrm{S} ; 102^{\circ} 20.989^{\prime} \mathrm{E}$, Desa Kaana

10. Sungai Kahyapu, $05^{\circ} 25.288^{\prime} \mathrm{S} ; 102^{\circ} 22.308^{\prime}$ E sebelah kantor BKSDA, Ds. Kahyapu

11. Alur sungai kecil, sebelah rumah mantan Kades Kahyapu, Ds. Kahyapu

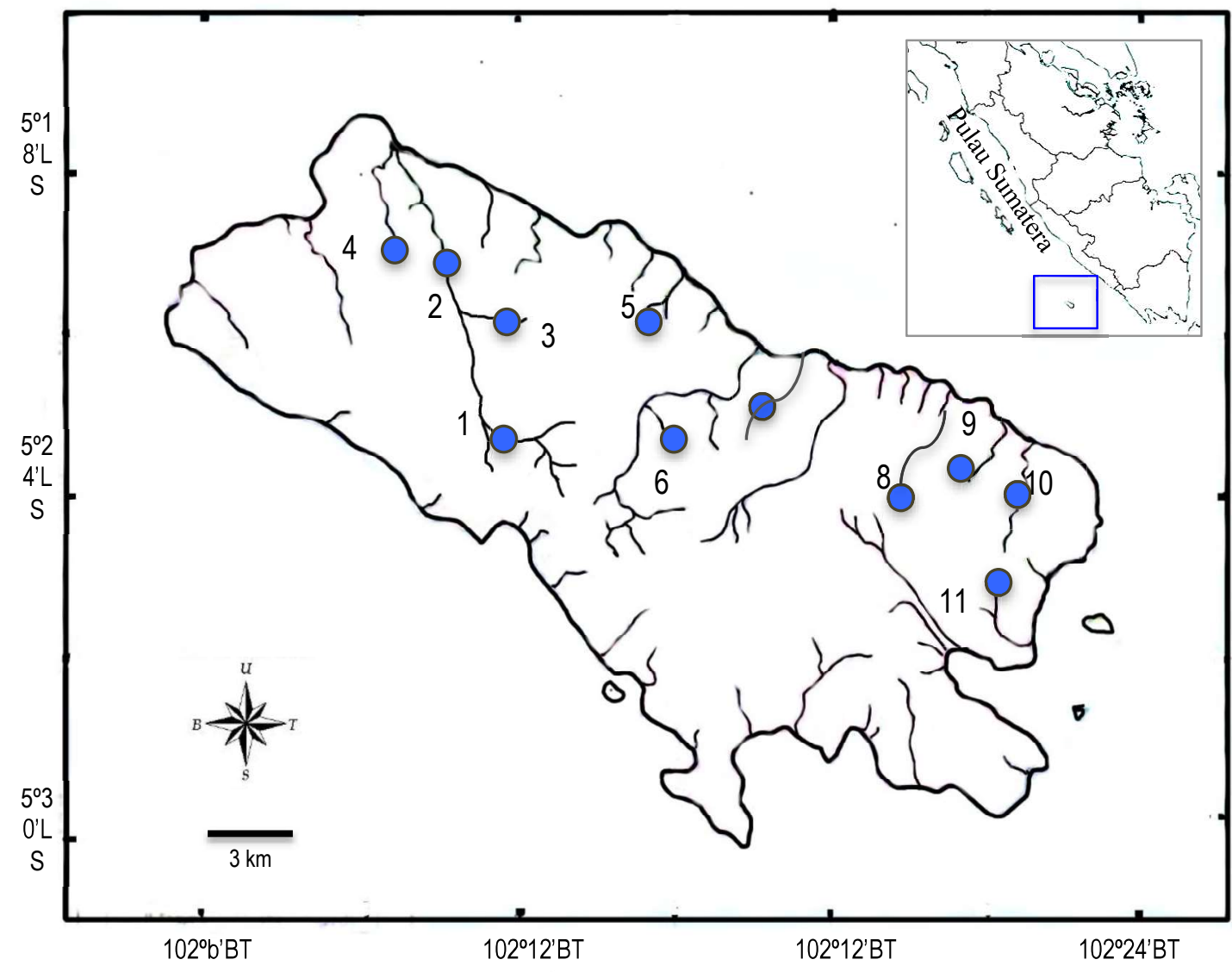

Gambar 1. Lokasi penelitian di Pulau Enggano: 1. S. Kamayan, 2. Sungai Kahabi, 3. S. Paubah, 4. S. Kinono, 5. S. Kikupu, 6. S. Anno, 7. S. Paco, 8. S. Kikuba, 9. S. Apiko, 10. S. Kahyapu, 11. Alur dekat mantan Kades Kahyapu. 
Koleksi, foto, dan fiksasi spesimen

Pengambilan contoh ikan dilakukan dengan menggunakan beberapa alat tangkap yaitu jaring tarik (seine net), setruman (electrosocker) dan serokan (tray net). Dari hasil koleksi dipilih beberapa ekor yang pola warna dan bentuk badannya terbaik dari jenis-jenis yang diperoleh. Ikan ini lalu dimasukkan dalam breathing bag untuk selanjutnya difoto dalam akuarium. Pola warna ikan selagi masih hidup didokumentasikan dan diambil segera setelah sampai di base camp dengan menggunakan kamera Nikon D80. Dokumentasi habitat ikan juga dilakukan.

Spesimen ikan lainnya dimasukkan kedalam botol nalgene, diberi label dan difiksasi dengan formalin 4\%. Nalgene diletakkan pada baki plastik yang datar, dengan tujuan agar bentuk ikan menjadi lurus dan bagus, yang akan memudahkan saat identifikasi di laboratorium. Setelah ikan terawetkan dengan baik, tubuh ikan lalu dibungkus dengan kain kasa dan dijaga cukup lembab. Pembungkusan dengan kain kasa bertujuan untuk mengurangi berat specimen pada saat dibawa ke laboratorium.

\section{Preparasi dan identifikasi}

Ikan dicuci dari formalin, direndam dalam air selama beberapa jam, lalu disortir berdasarkan morfologi, dan kemudian dimasukkan dalam botol kaca berisi alkohol 70\%. Botol yang digunakan disesuaikan dengan bentuk dan ukuran ikan tersebut. Selanjutnya ikan siap untuk diidentifikasi. Identifikasi dilakukan berdasarkan Allen (1991); Allen et al. (2000); Allen et al. (2008), Hoese \& Allen (1983), Keith et al. (2013), Kottelat et al. (1993), Kottelat (2013).

\section{Hasil}

Penelitian ikan air tawar di P. Enggano berhasil mendapatkan 457 spesimen. Hasil identifikasi menunjukkan bahwa ikan yang dikoleksi tergolong dalam 3 ordo, 11 famili dan 28 spesies (Tabel 1). Gobiidae merupakan famili yang terbanyak jenisnya (10 spesies) di perairan tawar $P$. Enggano, diikuti oleh Eleotridae yang terwakili oleh 5 spesies, Anguillidae dan Muraenidae dengan 3 spesies, Syngnathidae dan Kuhlidae diwakili 2 spesies, sedangkan 6 famili lainnya yaitu Anabantidae, Belontiidae, Channidae, Chandidae dan Apogonidae hanya 1 spesies (Gambar 1A).

Hasil koleksi di perairan tawar P. Enggano, Eleotridae merupakan famili yang terbanyak dikoleksi yaitu sejumlah 227 ekor atau 50\% dari total spesimen koleksi. Famili Gobiidae dikoleksi sejumlah 120 ekor atau 26\%, Familia Anguillidae dan Kuhlidae dikoleksi 24 ekor, Channidae dan Syngnathidae 21 ekor, Anabantidae 10 ekor; sedangkan Belontiidae, Opichthidae, Chandidae dan Apogonidae dikoleksi kurang dari 5 ekor (Gambar 1B).

Di perairan sungai, jumlah jenis tertinggi diperoleh dari S. Paco yaitu sejumlah 16 spesies, sedangkan di S. Kipupu dan S. Kikuba masingmasing dengan 12 dan 10 spesies (Gambar. 2). Di S Kahabi, S. Kahyapu dan Alur Kades diperoleh 7 jenis ikan, di S. Kinono dan S. Apiko didapat 4 jenis, sedangkan di S. Kamayan, S. Paubah dan S. Anno diperoleh tiga jenis ikan saja.

Hasil koleksi terbanyak juga diperoleh di S. Paco yaitu sebanyak 112 ekor, selanjutnya di S. Kipupu 75 ekor, S. Kikuba 69 ekor, Alur Kades 68, S. Kahabi 41 ekor sedangkan di sungai lainnya diperoleh ikan kurang dari 30 ekor. 
Tabel 1. Perolehan koleksi ikan di Pulau Enggano

\begin{tabular}{|c|c|c|c|c|c|c|}
\hline No & Ordo & No & Familia & No & Species & Total \\
\hline \multirow[t]{4}{*}{1} & Anguilliformes & 1 & Anguillidae & 1 & Anguilla bicolor & 10 \\
\hline & & & & 2 & Anguilla celebesensis & 1 \\
\hline & & & & 3 & Anguilla marmorata & 13 \\
\hline & & 2 & Opichthidae & 4 & Lamnostoma cf. mindora & 1 \\
\hline \multirow[t]{2}{*}{2} & Syngnathiformes & 3 & Syngnathidae & 5 & Microphis brachyurus & 9 \\
\hline & & & & 6 & Microphis sp. & 12 \\
\hline \multirow[t]{22}{*}{3} & Perciformes & 4 & Chandidae & 7 & Ambassis miops & 4 \\
\hline & & 5 & Kuhlidae & 8 & Kuhlia marginata & 10 \\
\hline & & & & 9 & Kuhlia rupestris & 14 \\
\hline & & 6 & Apogonidae & 10 & Apogon hyalosoma & 2 \\
\hline & & 7 & Eleotridae & 11 & Eleotris fusca & 165 \\
\hline & & & & 12 & Giuris margaritaceus & 30 \\
\hline & & & & 13 & Ophiocara ophicephalus & 3 \\
\hline & & & & 14 & Butis amboinensis & 5 \\
\hline & & & & 15 & Hypseleotris sp. & 24 \\
\hline & & 8 & Gobiidae & 16 & Glossogobius sp. & 41 \\
\hline & & & & 17 & Mugilogobius sp. & 1 \\
\hline & & & & 18 & Periophthalmus sp. & 1 \\
\hline & & & & 19 & Redigobius bikolanus & 10 \\
\hline & & & & 20 & Redigobius sp. & 12 \\
\hline & & & & 21 & Sicyopterus micrurus & 18 \\
\hline & & & & 22 & Sicyopterus sp. & 17 \\
\hline & & & & 23 & Stiphodon nsp.* & 8 \\
\hline & & & & 24 & Schismatogobius sp. & 7 \\
\hline & & & & 25 & Stenogobius sp. & 5 \\
\hline & & 9 & Anabantidae & 26 & Anabas testudineus & 10 \\
\hline & & 10 & Belontiidae & 27 & Trichopodus trichopterus & 3 \\
\hline & & 11 & Channidae & 28 & Channa striata\# & 21 \\
\hline
\end{tabular}

Keterangan: * Diduga jenis baru, \# Jenis ikan yang diduga diintroduksi ke P. Enggano

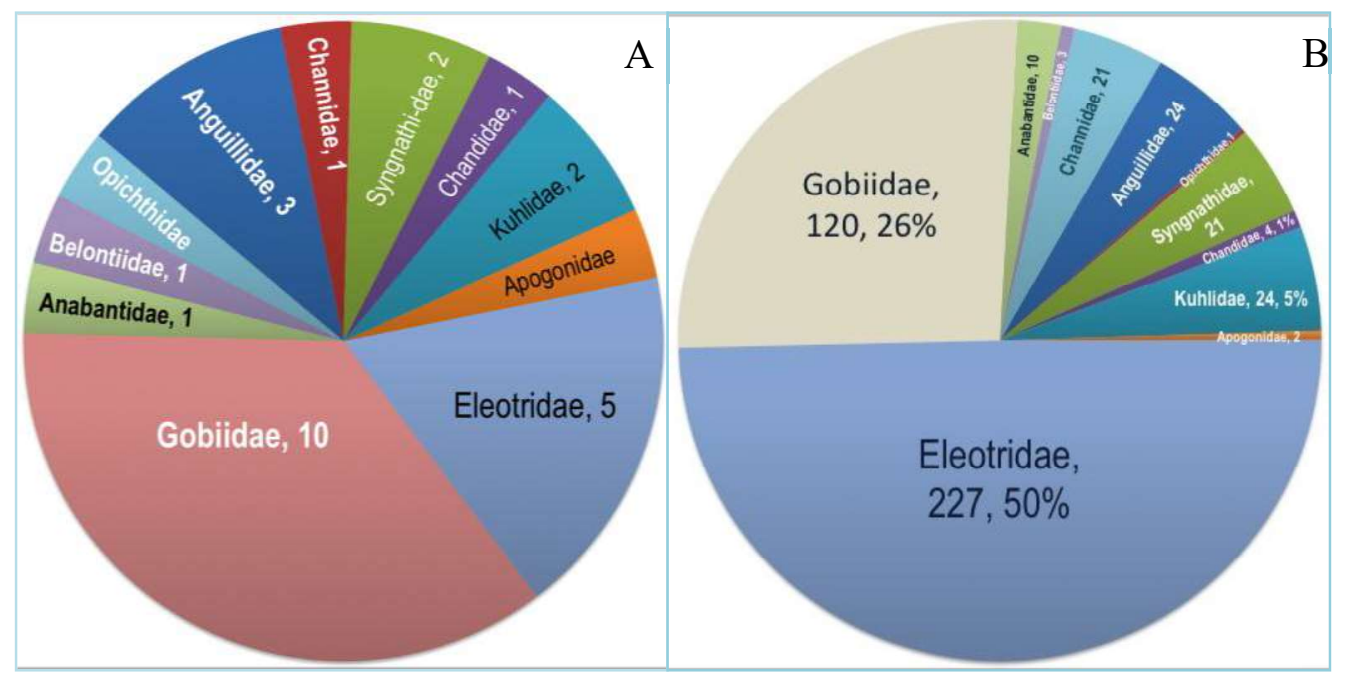

Gambar 1. Diagram hasil penelitian iktiofauna di P. Enggano: A. Familia dan jumlah jenis ikan; B. Familia, jumlah spesimen dan persentasinya 

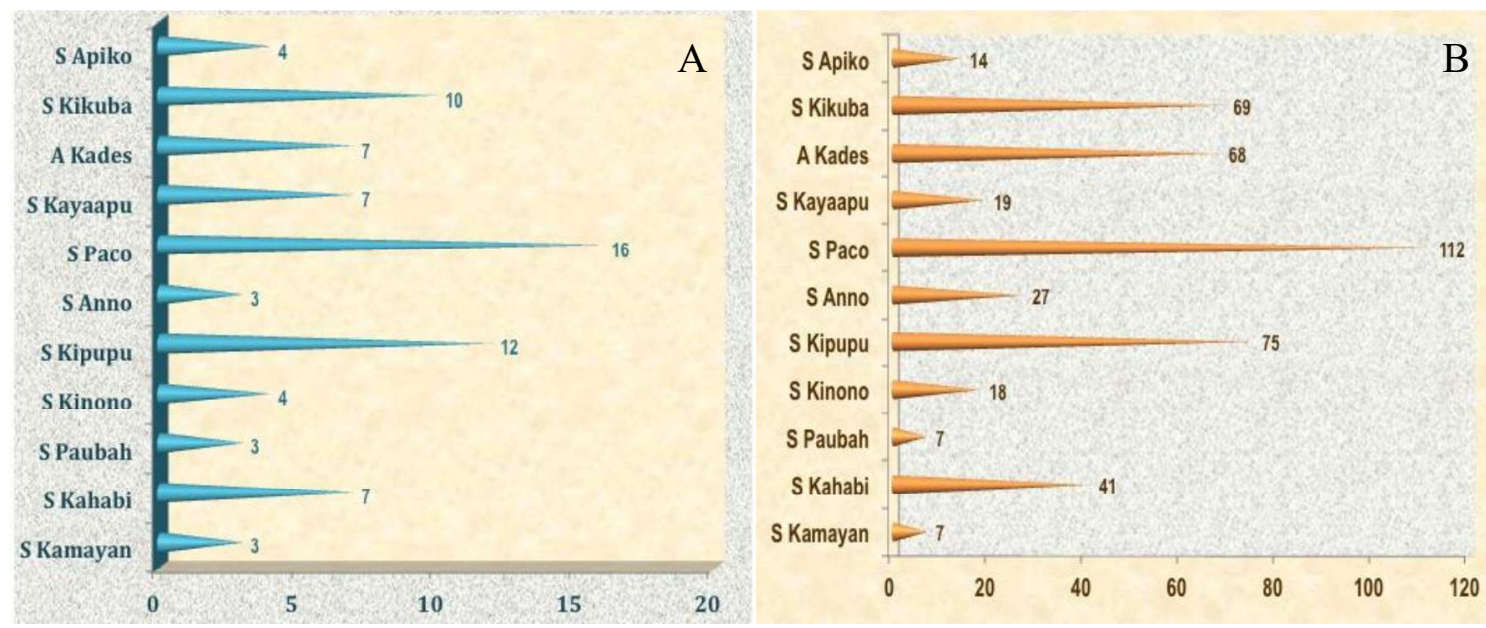

Gambar 2. Diagram hasil ikan air tawar di perairan sungai P. Enggano: A. Sungai dan jumlah spesies; B. Sungai dan jumlah spesimen.

\section{Pembahasan}

Dari 28 jenis ikan yang berhasil dikoleksi di perairan tawar P. Enggano, didominasi oleh famili Gobiidae yang terdiri atas 10 jenis yaitu Asterropteryx sp., Amblygobius cf phalaena, Glossogobius sp., Istigobius sp., Mugilogobius sp., Periophthalmus argentimaculatus, Redigobius bikolanus, Redigobius sp., Sicyopterus micrurus, Sicyopterus sp., Stiphodon nsp., Schismatogobius sp. dan Stenogobius sp.. Baru dua dari sepuluh jenis gobiid yang telah diketahui spesiesnya, sehingga perlu diteliti lebih lanjut karena grup ini berukuran kecil. Karakter kuncinya adalah pori-pori di kepala, gigi geligi, sisik yang memerlukan waktu khusus untuk mengidentifikasinya.

Selama ini hasil penelitian di wilayah perairan Indonesia bagian barat menunjukkan bahwa Famili Cyprinidae mendominasi perolehan koleksi ikan (Hadiaty 2001a, 2005, 2011ab, Hadiaty \& Sauri 2014), sedangkan di wilayah Indonesia bagian timur Famili Gobiidae mendominasi perolehan jenis ikan (Hadiaty 1996,
2008, 2009, Hadiaty et al. 2012). Dominasi ikan gobiid di P. Enggano menyerupai perolehan koleksi di Indonesia bagian timur, sekalipun pulau ini berada di wilayah Indonesia bagian barat. Hal ini sesuai dengan sejarah geografis pulau ini yang tidak pernah menyatu dengan P. Sumatera, seperti halnya pulau-pulau di Indonesia timur yang tidak pernah menyatu dengan paparan Sunda atau Sahul seperti tertera dalam peta Asia Tenggara yang disampaikan oleh Voris (2000). Sebagian besar Famili Gobiidae hidup di laut. Jenis-jenis ikan gobiid yang hidup di air tawar saat ini merupakan hasil adaptasi dalam waktu yang sangat lama.

Satu jenis ikan gobiid di P. Enggano sangat menarik yaitu Stiphodon nsp. (Gambar 3a) yang diduga merupakan jenis baru. Ikan ini punya pola warna yang sangat jauh berbeda bila dibandingkan dengan jenis-jenis Stiphodon yang telah dideskripsi sebelumnya. Pola warna tubuhnya seperti warna pelangi: biru muda, kuning, merah jambu dari kepala sampai ke ekornya. Saat mendapat spesimen pertama jenis ini di S. Paco, 


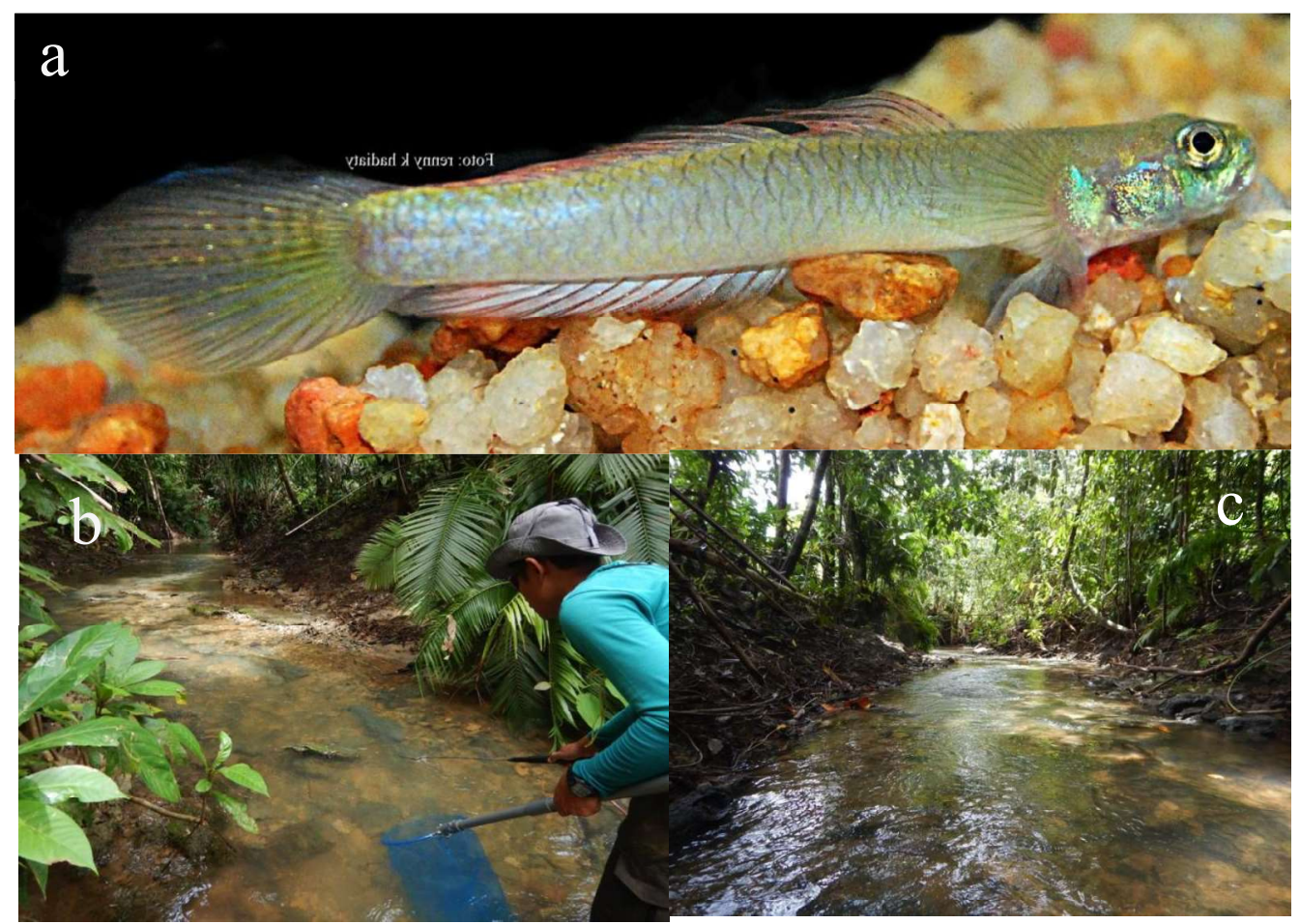

Gambar 3. Hasil koleksi di Sungai Paco: a. Ikan yang diduga merupakan jenis baru, Stiphodon nsp.; b-c. Sungai Paco yang berair jernih, dangkal dan berbatu, habitat yang nyaman bagi genus ini.

dengan penuh semangat kami menyusur ke arah hulu, mencarinya di habitat berbatu yang airnya mengalir cukup deras. Hasil koleksi mendapatkan delapan spesimen yang saat ini dideposit di Laboratorium Iktiologi dengan nomor MZB 22822. Selanjutnya, spesies ini akan dideskripsikan sebagai jenis baru.

Hasil penelitian di 11 perairan tawar P. Enggano, koleksi di S. Paco tertinggi jumlah spesiesnya yaitu 16 jenis, diikuti oleh S. Kipupu dengan 12 jenis dan S. Kikuba dengan 10 jenis, dari Alur Kades dijumpai 8 jenis, sedangkan di S. Kayaapu dan S Kahabi dijumpai 7 jenis. Dari lima sungai lainnya hanya dijumpai kurang dari 5 jenis (Gambar 2A). Dari perolehan spesimen, S. Paco tertinggi yaitu 112 ekor, S. Kipupu 75 ekor, S. Kikuba 69 ekor dan Alur Kades 68 ekor, sedangkan ke tujuh sungai lainnya diperoleh spesimen kurang dari 50 ekor (Gambar 2B). Dari perolehan ini jelas terlihat bahwa perairan di wilayah barat (S. Kamayan, S. Kahabi, S. Paubah, dan S. Kinono) perolehan jenis dan jumlah spesimen lebih sedikit daripada wilayah tengah (S. Paco, S. Kipupu \& S. Anno) dan timur (S. Kayaapu, Alur Kades $<$ S. Kikuba \& S. Apiko) dari P. Enggano. Hal ini disebabkan di wilayah barat, banyak pendatang dari Jawa, dekat dengan wilayah transmigran, sungainya relatif panjang dan jauh dari pantai. Banyak penduduk mencari ikan di sungai untuk memenuhi kebutuhan protein hewani. Alat yang digunakan adalah setrum atau electric fishing. Dengan demikian jumlah spesies dan spesimen yang diperoleh lebih sedikit dibandingkan dengan jenis dan spesimen ikan dari wilayah tengah dan timur P. Enggano, yang letaknya memang relatif dekat dengan pantai sehingga penduduk lebih memilih untuk mendapatkan ikan dari laut.

Jenis ikan air tawar yang terbanyak dikoleksi di P. Enggano adalah Eleotris fusca (Gambar 4a) 
yaitu sebanyak 166 ekor. Ikan ini dijumpai di 10 lokasi penelitian. Dua jenis ikan yang sudah diketahui dari perairan P Enggano oleh Perugia (1893) adalah jenis Acentrogobius janthinopterus dan Butis amboinensis. Hasil penelitian kami berhasil mengoleksi B. amboinensis (Gambar 4b), namun tidak berhasil mendapatkan $A$. janthinopterus.

Beberapa jenis ikan lain yang menarik dari perairan di P. Enggano antara lain Hypseleotris sp., Redigobius sp., Stenogobius sp. dan Schismatogobius sp. (Gambar 5). Tidak tertutup kemungkinan bila jenis-jenis ini merupakan spesies endemik di P. Enggano, namun diperlukan penelitian lebih lanjut dan waktu khusus untuk mengetahui status taksonominya.

Dua jenis diduga diintroduksi ke P. Enggano yaitu Channa striata (lebih dikenal sebagai ikan gabus) dan Trichopodus trichopterus (sepat), namun tidak diketahui waktu introduksinya. Sebetulnya ada informasi yang menyatakan bahwa di Desa Banjarsari (transmigran) masyarakat membudidayakan ikan yang bukan berasal dari Indo- nesia yaitu lele dumbo, Clarias gariepinus dan mujair Oreochromis mossambicus. Namun kami tidak berkesempatan untuk mengoleksinya. Hal yang menggembirakan bahwa jenis-jenis introduksi tersebut tidak meluas ke wilayah tengah dan timur perairan P. Enggano. Jenis-jenis ikan introduksi kemungkinan dibawa oleh para transmigran dari P. Jawa yang bermukim di Desa Banjarsari, demikian pula dengan kebiasaan untuk mengambil ikan dengan electric fishing.

Koleksi di dusun Bendung dilakukan di perairan hulu sungai yang relatif jauh dari muara menyebabkan hampir tiap rumah memiliki electric fishing untuk memenuhi kebutuhan protein hewani dengan mencari ikan di sungai. Target utama penangkapan adalah ikan sidat (Anguilla spp.) dan gabus (Channa striata), namun kegiatan ini berimbas pada biodiversitas ikan di sungai. Koleksi selama tiga hari hanya mendapatkan tujuh jenis ikan dan tidak terlihat anakan ikan yang berenang di tepi perairan. Jumlah jenis dan spesimen koleksi di wilayah ini paling sedikit dibanding di tengah dan timur pulau.

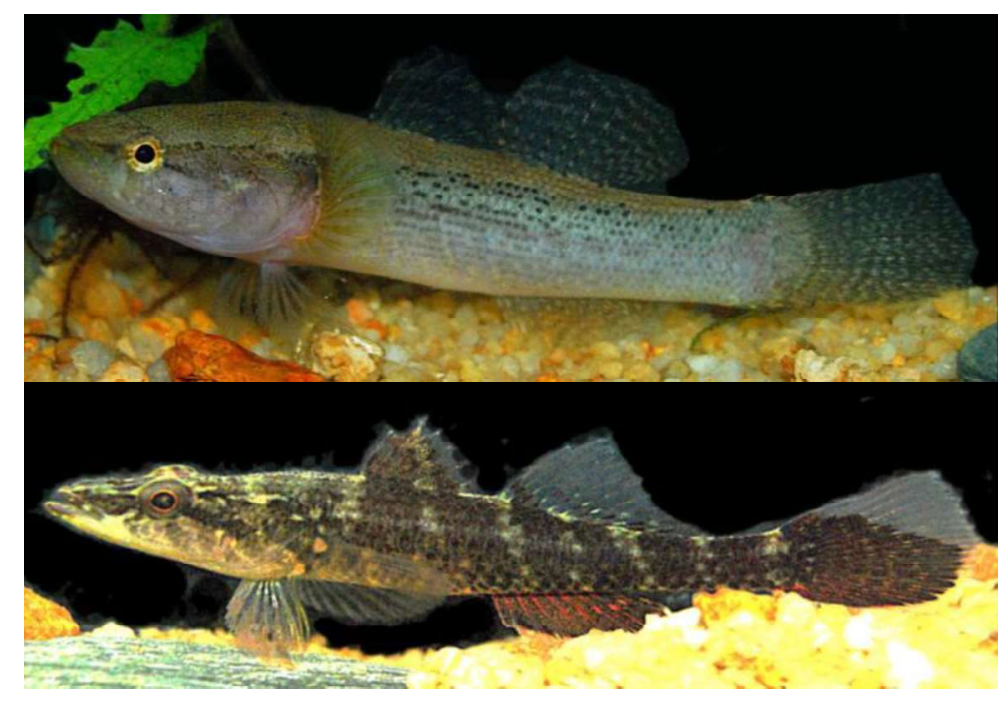

Gambar 4. Ikan yang paling umum dijumpai di perairan P. Enggano: a. Eleotris fusca; b. ikan Butis amboinensis 


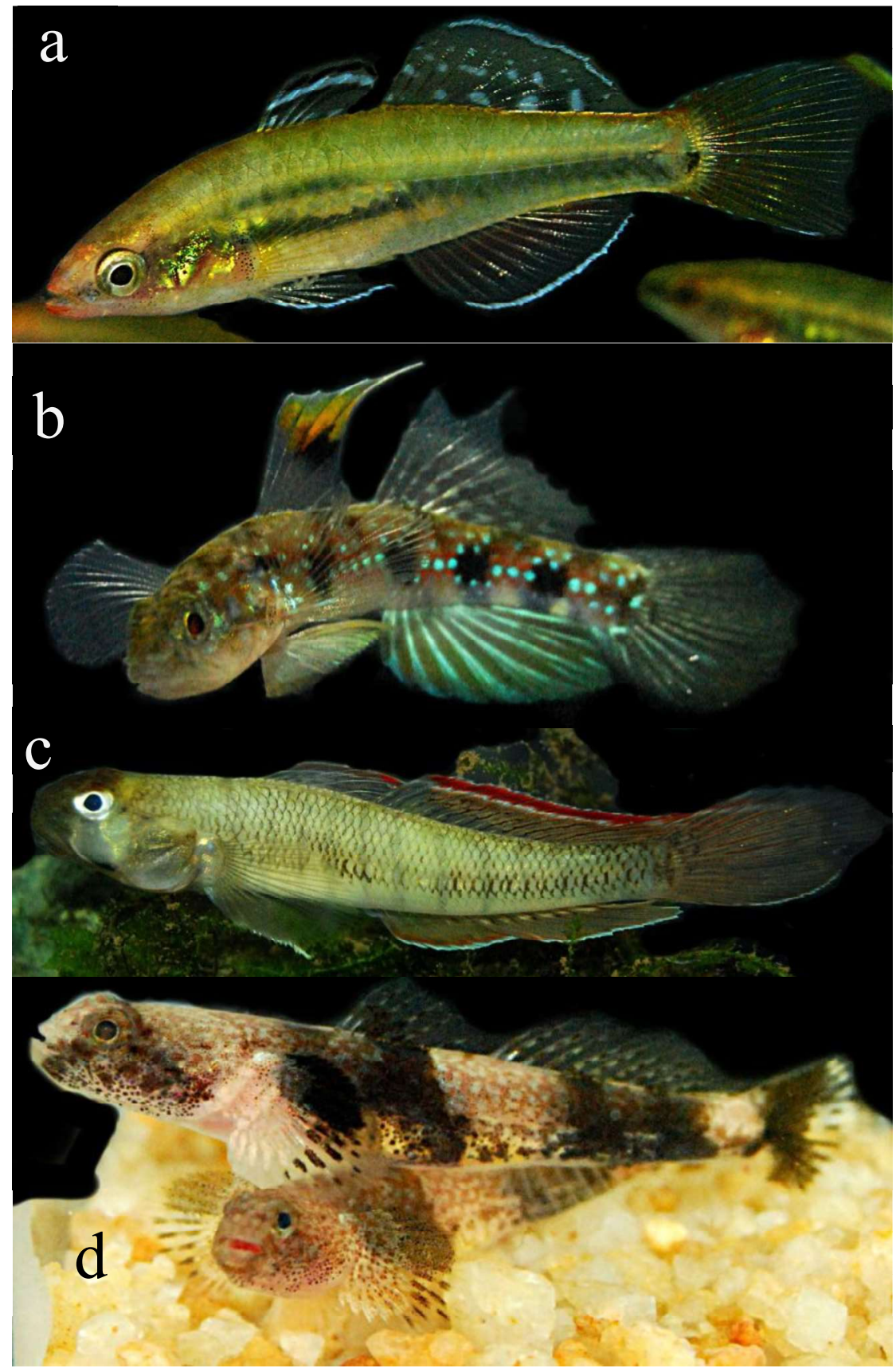

Gambar 5. Beberapa jenis ikan yang perlu diteliti lebih lanjut dari perairan P Enggano: a. Hypseleotris sp., b. Redigobius sp. c. Stenogobius sp. dan d. Schismatogobius sp. 

Tabel 2. Nama dan jumlah spesies hasil koleksi di P. Enggano yang dideposit di Museum Zoologicum Bogoriense (MZB)

\begin{tabular}{|c|c|c|c|}
\hline No & Nama Spesies & Jumlah (individu) & Nomor MZB \\
\hline 1 & Giuris margaritaceus & 3 & 22784 \\
\hline 2 & Anguilla marmorata & 1 & 22785 \\
\hline 3 & Channa striata & 3 & 22786 \\
\hline 4 & Anguilla marmorata & 2 & 22787 \\
\hline 5 & A. celebesensis & 1 & 22788 \\
\hline 6 & Anguilla bicolor & 1 & 22789 \\
\hline 7 & Eleotris fusca & 8 & 22790 \\
\hline 8 & Channa striata & 10 & 22791 \\
\hline 9 & Sicyopterus micrurus & 2 & 22792 \\
\hline 10 & Sicyopterus sp. & 17 & 22793 \\
\hline 11 & Anabas testudineus & 1 & 22794 \\
\hline 12 & Sicyopterus micrurus & 5 & 22795 \\
\hline 13 & Eleotris fusca & 1 & 22796 \\
\hline 14 & Anguilla marmorata & 2 & 22797 \\
\hline 15 & Channa striata & 3 & 22798 \\
\hline 16 & Sicyopterus micrurus & 2 & 22799 \\
\hline 17 & Eleotris fusca & 11 & 22800 \\
\hline 18 & Anguilla bicolor & 1 & 22801 \\
\hline 19 & Anabas testudineus & 4 & 22802 \\
\hline 20 & Ambassis miops & 1 & 22803 \\
\hline 21 & Channa striata & 1 & 22804 \\
\hline 22 & Eleotris fusca & 11 & 22805 \\
\hline 23 & Ophiocara ophicephalus & 3 & 22806 \\
\hline 24 & Giuris margaritaceus & 3 & 22807 \\
\hline 25 & Hypseleotris sp. & 24 & 22808 \\
\hline 26 & Kuhlia rupestris & 7 & 22809 \\
\hline 27 & Microphis brachyurus & 4 & 22810 \\
\hline 28 & Microphis sp. & 4 & 22811 \\
\hline 29 & Redigobius sp. & 12 & 22812 \\
\hline 30 & Eleotris fusca & 21 & 22813 \\
\hline 31 & Giuris margaritaceus & 4 & 22814 \\
\hline 32 & Glossogobius sp. & 2 & 22815 \\
\hline 33 & Anguilla marmorata & 4 & 22816 \\
\hline 34 & Anguilla bicolor & 3 & 22817 \\
\hline 35 & Eleotris cf. fusca & 47 & 22818 \\
\hline 36 & Lamnostomma sp. & 1 & 22819 \\
\hline 37 & Stenogobius sp. & 3 & 22820 \\
\hline 38 & Butis amboinensis & 5 & 22821 \\
\hline 39 & Stiphodon nsp. & 8 & 22822 \\
\hline 40 & Kuhlia rupestris & 1 & 22823 \\
\hline 41 & Giuris margaritaceus & 3 & 22824 \\
\hline 42 & Periophthalmus argentilineatus & 1 & 22825 \\
\hline 43 & Mugilogobius sp. & 1 & 22826 \\
\hline 44 & Channa striata & 1 & 22827 \\
\hline 45 & Microphis sp. & 4 & 22828 \\
\hline 46 & Microphis brachyurus & 3 & 22829 \\
\hline 47 & Redigobius bikolanus & 10 & 22830 \\
\hline 48 & Glossogobius sp. & 17 & 22831 \\
\hline 49 & Anabas testudineus & 5 & 22832 \\
\hline 50 & Channa striata & 3 & 22833 \\
\hline 51 & Trichopodus trichopterus & 3 & 22834 \\
\hline 52 & Apogon sp. & 2 & 22835 \\
\hline 53 & Ambassis miops & 3 & 22836 \\
\hline
\end{tabular}


Tabel 2. (lanjutan) Nama dan jumlah spesies hasil koleksi di P. Enggano yang dideposit di Museum Zoologicum Bogoriense (MZB)

\begin{tabular}{llcc}
\hline No & Nama Spesies & Jumlah (individu) & Nomor MZB \\
\hline 54 & Microphis brachyurus & 2 & 22837 \\
55 & Microphis sp. & 1 & 22838 \\
56 & Anguilla bicolor & 4 & 22839 \\
57 & Eleotris fusca & 24 & 22840 \\
58 & Schismatogobius sp. & 5 & 22841 \\
59 & Stenogobius sp. & 1 & 22842 \\
60 & Kuhlia marginata & 6 & 22843 \\
61 & Microphis sp. & 1 & 22844 \\
62 & Glossogobius sp. & 15 & 22845 \\
63 & Giuris margaritaceus & 12 & 22846 \\
64 & Anguilla marmorata & 3 & 22847 \\
65 & Giuris margaritaceus & 3 & 22848 \\
66 & Microphis sp. & 2 & 22849 \\
67 & Schismatogobius sp. & 2 & 22850 \\
68 & Kuhlia rupestris & 6 & 22851 \\
69 & Kuhlia marginata & 4 & 22852 \\
70 & Glossogobius sp. & 7 & 22853 \\
71 & Stenogobius sp. & 1 & 22854 \\
72 & Sicyopterus micrurus & 9 & 22855 \\
73 & Eleotris fusca & 32 & 22856 \\
74 & Anguilla bicolor & 1 & 22857 \\
75 & Anguilla marmorata & 1 & 22858 \\
76 & Eleotris fusca & 10 & 22859 \\
77 & Giuris margaritaceus & 2 & 22860 \\
\hline & & 457 & \\
\hline
\end{tabular}

Di bagian tengah dan timur pulau, ikan sungai tidak dicari oleh penduduk karena permukiman berada di tepi pantai, sehingga mereka lebih menyukai untuk mencari ikan di laut. Hal ini menyebabkan ikan sungai tidak terganggu, terlihat dari perolehan koleksi ikan dengan jenis dan jumlah ikan yang lebih banyak.

Semua kegiatan koleksi iktiofauna di P. Enggano dilakukan di sungai-sungai yang mengalir ke arah utara dan di pantai sebelah utara. Data keanekaragaman iktiofauna di pulau ini akan lebih lengkap bila ada kesempatan untuk melakukan penelitian di perairan sungai atau pantai yang mengalir ke sebelah selatan P. Enggano. Diduga akan diperoleh penambahan jenis ikan yang hidup di P. Enggano, mungkin akan dapat diperoleh ikan yang pernah dikemukakan oleh Perugia yaitu Acentrogobius janthinopterus dan jenis-jenis lainnya. Dua jenis ikan air tawar telah dilakukan oleh Perugia tahun 1893, yaitu jenis
Acentrogobius janthinopterus dan Butis amboinensis. Ke dua jenis tersebut disimpan di Museo Civico di Storia Naturale di Genova (MSNG) dengan nomor MSNG 12659 dan 12691.

Penelitian ikan air tawar di P. Enggano belum pernah dilakukan peneliti Indonesia sebelumnya, sehingga semua koleksinya merupakan rekor baru untuk Museum Zoologicum Bogoriense (MZB). Semua spesimen, 457 ekor dari 11 perairan P. Enggano tersebut telah diregistrasi dan dimasukkan dalam buku katalog di Laboratorium Iktologi, Bidang Zoologi, Pusat Penelitian Biologi. Koleksi ikan tersebut telah dicatat dalam 77 nomor MZB (Tabel 2).

Satu hal yang perlu mendapat perhatian terjadi di S. Apiko yang dikenal juga dengan nama Sungai Dam Seng di Desa Kaana. Dikatakan demikian karena sungai ini dibendung menggunakan pintu besi dan seng. Sungai ini dibendung untuk mengaliri sawah di sekitar area tersebut. 
Akibatnya, tidak ada ikan gobiid Sicyopterus, Stiphodon dan lainnya di arah hulu dari dam tersebut. Ikan Gobiidae bersifat amfidromous, yaitu tumbuh dan memijah di perairan tawar namun anakannya akan menuju ke laut, berkembang di laut, namun akan kembali lagi ke perairan darat dan mengalami metamorfosis menjadi dewasa dan bereproduksi (Keith et al. 2015b).

Guna melestarikan keanekaragaman iktiofauna di Pulau Enggano, sebaiknya ada pembatasan atau peraturan dalam penggunaan electric fishing terutama di daerah hulu, yang jauh dari pantai. Pada sungai yang dibendung, sebaiknya dibuat aliran (run way) bagi anakan ikan yang akan kembali ke sungai. Beberapa jenis ikan misalnya sidat, Anguilla spp. dan mungkus, Sicyopterus spp. melakukan pemijahan di perairan laut, anakannya akan kembali ke sungai. Apabila dilakukan pembendungan untuk irigasi maka anakan ikan tidak dapat kembali ke sungai, sehingga di bagian hulu tidak ada lagi jenis-jenis ikan tersebut.

\section{Simpulan}

Telah diperoleh 28 jenis ikan yang tergolong dalam 11 familia, 3 ordo. Koleksi di 11 perairan P. Enggano yang terdiri atas 10 sungai dan 1 alur sungai berhasil mendapatkan 457 ekor ikan. Koleksi tersebut merupakan rekor baru untuk MZB dan telah dicatat dalam 77 nomor, yaitu MZB 22784 sampai dengan MZB 22860. Satu jenis diantaranya, Stiphodon sp diduga merupakan jenis baru, beberapa jenis lainnya seperti Hypseleotris sp., Redigobius sp., Stenogobius sp.dan Schismatogobius sp. perlu diteliti lebih lanjut untuk mengetahui status taksonominya.

\section{Persantunan}

Ucapan terima kasih disampaikan kepada para pimpinan LIPI. Penghargaan dan rasa terima kasih kami sampaikan pula pada para koordinator proyek P. Enggano, Amir Hamidy, Sigit Wiantoro, Oscar, Ujang Nurhaman serta semua tim LIPI tim ekspedisi P. Enggano. Rasa kebersa-maan, senasib sepenanggungan dan kekompakan yang terjalin sangat menunjang kegiatan penelitian. Terima kasih pada Bapak dan Ibu Bambang yang menampung kami di rumah dan halaman beliau, Mas Slamet yang membantu menangkap ikan dengan tambahan elektrik fishingnya di Dusun Bendung, Desa Banjarsari. Terima kasih pada Bapak dari BKSDA P. Enggano, Keluarga Bapak bekas kepala desa Kahyaapu dan semua yang telah membantu selama pelaksanaan kegiatan penelitian ini.

\section{Daftar pustaka}

Adrim M. 2007. Komunitas ikan karang di perairan Pulau Enggano, Provinsi Bengkulu. Oseanologi dan Limnologi di Indonesia, 33(1): 139-158.

Allen GR. 1991. Field Guide to the Freshwater Fishes of New Guinea. Christensen Research Institute, Madang.

Allen GR, Kent GH, Renyaan SJ. 2000. Freshwater Fishes of the Timika Region New Guinea. Perth, Western Australia, P.T. Freeport Indonesia and Tropical Reef Research.

Allen GR, Unmack PJ, Hadiaty RK. 2008: Two new species of rainbowfishes (Melanotaenia: Melanotaeniidae), from, western New Guinea (Papua Barat Province, Indonesia). Aqua International Journal of Ichthyology, 14 (4): 209-224

Allen GR, Hadiaty RK. 2011. A new species of rainbowfish (Melanotaeniidae) from western New Guinea (West papua Province, Indonesia). ANGFA, Fishes of Sahul, 25(1): 601-607.

Allen GR, Hadiaty RK. 2013. Melanotaenia sneideri, a new species of rainbowfish (Melanotaeniidae) from West Papua Province, Indonesia. Aqua International Journal of Ichthyology, 19 (3): 137-146.

Allen GR, Hadiaty RK. 2014. Two new species of freshwater gudgeons (Eleotridae: Mor- 
gurnda) from the Arguni Bay Region of West Papua, Indonesia. Aqua International Journal of Ichthyology, 20(2): 97110.

Allen GR, Hadiaty RK, Unmack PJ. 2014. Melanotaenia flavipinnis, a new species of Rainbowfish (Melanotaeniidae) from Misool island, West Papua Province, Indonesia. Aqua International Journal of Ichthyology, 20(1): 35-52.

Allen GR, Hadiaty RK, Unmack PJ, Erdmann MV. 2015a. Rainbowfishes (Melanotaenia: Melanotaeniidae) of the Aru Islands, Indonesia with descriptions of five new species and redescription of $M$. patoti Weber and $M$. senckenbergianus Weber. Aqua International Journal of Ichthyology, 21(2): 66-108.

Allen GR, Unmack PJ, Hadiaty RK. 2015b. Melanotaenia rubrivittata, a new species of rainbowfish (Melanotaeniidae) from Northwestern Papua Province, Indonesia. Fishes of Sahul, 29 (1): 846-858

Allen GR, Erdmann MV, Hadiaty RK. 2015c. Acentrogobius limarius a new species of goby (Pisces: Gobiidae) from West Papua Province, Indonesia. Journal of the Ocean Science Foundation 15: 33-40.

Badan Informasi Geospasial (BIG). 2015. http:// www.bakosurtanal.go.id/berita-surta/ show/indonesia-memiliki-13-466-pulauyang-terdaftar-dan-berkoordinat. Diakses tanggal 31 Oktober 2015.

Eschmeyer WN, Fricke R (eds). 2015. Catalog of Fishes: Genera, Species, References. http: //researcharchive.calacademy.org/research /ichthyology/catalog/fishcatmain.asp. Elec tronic version accessed 2 April 2015.

Graf JA, Herder F, Hadiaty RK. 2015. A new species of rainbowfish (Melanotaeniidae), Melanotaenia garylangei, from western new guinea (Papua Province, Indonesia). ANGFA, Fishes of Sahul 29(2): 870-881.

Hadiaty RK.1996. Keanekaragaman jenis ikan dan ekosistemnya di Taman Nasional Bogani-nani Wartabone, Sulawesi Utara. Laporan teknik penelitian dan pengembangan biota berdaya guna, Puslitbang Biologi - LIPI .

Hadiaty RK. 2001a. Fauna ikan di Cagar Alam Muara Kendawangan, Kalimantan Barat. Jurnal Iktiologi Indonesia, 1(2): 1-9.
Hadiaty RK. 2001b. A new record of Puntius gemellus from Muara Kendawangan Reserve Nature, West Kalimantan. Zoo Indonesia 28: 36-37.

Hadiaty RK. 2003a. Sejarah penelitian dan potensi pengembangan fauna ikan asli Jabodetabek di areal situ-situ. In: Ubaidillah \&Maryanto (Eds.). Manajemen Bioregional Jabodetabek: Profil dan Strategi Pengelolaan Situ, Rawa dan Danau. Pusat Penelitian Biologi-LIPI.

Hadiaty RK. 2003b. Struktur bibir ikan Osteochilus partilineatus Kott. dan perbandingannya dengan 7 jenis Osteochilus lainnya. Berita Biologi, 6(4): 583-588.

Hadiaty RK. 2003c. Kajian morfologi Parosphromenus spp. (Teleostei: Belontiidae) di Indonesia. Ekologia, 3(2): 21-27.

Hadiaty RK. 2005. Keanekaragaman jenis ikan di Taman Nasional Gunung Leuser, Sumatera. Jurnal Biologi Indonesia, 3(9): 379- 388.

Hadiaty RK. 2007. Kajian ilmiah ikan pelangi, Marosatherina ladigesi (Ahl 1936), Fauna endemik Sulawesi. Berita Biologi, 8(6): 473-479.

Hadiaty RK. 2008. Biodiversitas ikan di Pulau Waigeo, Kabupaten Raja Ampat, Propinsi Papua. Laporan Teknik. Pusat Penelitian Biologi.

Hadiaty RK. 2009. Biodiversitas ikan di Pulau Batanta, Kabupaten Raja Ampat, Propinsi Papua. Laporan Teknik. Pusat Penelitian Biologi.

Hadiaty RK. 2011a. Diversitas dan hilangnya jenis-jenis ikan di Sungai Ciliwung dan Sungai Cisadane. Berita Biologi, 10(4): 491-504.

Hadiaty RK. 2011b. Diversitas dan kehilangan jenis ikan di danau-danau aliran Sungai Cisadane. Jurnal Iktiologi Indonesia, 11(2): 143-157.

Hadiaty RK. 2012. Ikan. In: Suhardjono \& Ubaidillah (Eds.). Fauna Karst dan Gua Maros, Sulawesi Selatan. LIPI Press.

Hadiaty RK, Siebert DJ 1998. Two new species of Osteochilus (Teleostei: Cyprinidae) from Sungai Lembang, Suag Balimbing Research Station, Gunung Leuser National Park, Aceh, Nordwestern Sumatra. Revue Franchaise d'Aquariologie Herpetologie Journal, 25 (1-2): 1-4. 
Hadiaty RK, Siebert DJ. 2003. Sex dimorphism and notes on the biology of Osteochilus partilineatus Kott from Putat River, Sanggau, West Kalimantan. Jurnal Ilmu-ilmu Perairan dan Perikanan Indonesia, 10(2): 117-120).

Hadiaty RK, Rachmatika I. 2003. Morphological structure of Latimeria menadoensis scales. Treubia 33(1): 1-11.

Hadiaty RK, Wirjoatmodjo S. 2003. Studi pendahuluan: Biodiversitas dan distribusi ikan endemik di Danau Matano, Sulawesi Selatan. Jurnal Iktiologi Indonesia, 2(2): 23-29.

Hadiaty RK, Nyanti L, Zainuddin, Suhitno. 2003. Biodiversity and Distribution of the Fishes at Pa'Raye, Kayan Mentarang $\mathrm{Na}$ tional Park, East Kalimantan, Indonesia. A joint expedition between Indonesia and Malaysia, Funded by ITTO, Dept. of Forestry, LIPI. Published in CD version.

Hadiaty RK, Wirjoatmodjo S, Sulistiono, MF Rahardjo. 2004. Perjalanan dan koleksi ikan di Danau Mahalona, Lantoa dan Masapi, Sulawesi Selatan. Jurnal Iktiologi Indonesia, 4(1): 31-42.

Hadiaty RK, Siebert DJ. 2001. Nemacheilus tuberigum, a new species of loach (Teleostei: Balitoridae) from Aceh, northwestern Sumatra, Indonesia. Bulletin of Natural History Museum London (Zoology), 67(2): 183-189.

Hadiaty RK, Kottelat M. 2009a. Rasbora lacrimula, a new species of cyprinid fish from eastern Borneo (Teleostei: Cyprinidae). Ichthyological Exploration Freshwater Journal, 20 (2): 105-109.

Hadiaty RK, Kottelat M. 2009b. Pangio lidi, a new species of loach from eastern Borneo, Indonesia (Teleostei: Cobitidae). Zootaxa 2171: 65-68 (2009).

HadiatyRK, Kottelat M. 2009c. Nemacheilus tebo, a new loach from Sangkulirang Karst, East Kalimantan, Indonesia (Teleostei: Nemacheilidae). Raffless Bulletin of Zoology, 57(1): 119-125.

Hadiaty RK, Kottelat M. 2010. Nemacheilus marang, a new loach (Teleostei: Nemacheilidae) from Sangkulirang karst, Eastern Borneo.Zootaxa 2557: 39-48.
Hadiaty RK, Allen GR, Erdmann MV. 2012. Keanekaragaman jenis ikan Kaimana, Papua Barat. Zoo Indonesia, 21(2): 35-42.

Hadiaty RK, Sauri S. 2014. Diversitas ikan air tawar di DAS Selalir, Tau Lumbis, Kalimantan Utara. In Irham M, Dewi K (Editor). Keanekaragaman Hayati di Beranda Negeri: PT Eaststar Adhi Citra. pp 197207

Hadiaty RK, Allen GR. 2011. Glossamia nsp., a new species of freshwater cardinalfish (Apogonidae) from West Papua Province, Indonesia). Aqua Journal of Ichthyology, 17(3): 173-180

Hoese DF, Allen GR. 1983. A review of the Gudgeon Genus Hypseleotris (Pisces: Eleotridae) of Western Australia, with descriptions of three new species. Record of Western Australia Museum, 10 (3): 243-261

Hoese DF, Hadiaty RK, Herder F. 2015. Review of the dwarf Glossogobius lacking head pores from the Malili Lakes, Sulawesi, with a discussion of the definition of the genus. Raffless Bulletin of Zoology 63 (1): 14-26.

Hoese D, Allen GR, Hadiaty RK. 2017. Description of three new species of dwarf Glossogobius from New Guinea and northern Australia. Cybium, 41(2): 179-193.

Keith P, Hadiaty RK, Lord C. 2012. A new species of Belobranchus (Teleostei: Gobioidei: Eleotridae) from Indonesia. Cybium, 36(3): 479-484.

Keith P, Marquet G, Gerbeaux P, Vigneux E, Lord C. 2013. Freshwater Fish and Crustaceans of Polynesia: Taxonomy, Ecology, Biology and Management. Société Française d'Ichthyologie, Paris. 282 p.

Keith P, Hadiaty RK. 2014. Stiphodon annieae, a new species of freshwater goby from Indonesia (Gobiidae). Cybium, 38(4): 267272 .

Keith P, Hadiaty RK, Busson F, Hubert N. 2014. A new species of Sicyopus (Gobiidae) from Java and Bali. Cybium 38(3): 173178.

Keith P, Hadiaty RK, Hubert N, Busson F, Lord C. 2014. Three new species of Lentipes from Indonesia. Cybium, 38(2): 133-146. 
Keith P, Lord C, Maeda K. 2015b. Indo-Pacific Sicydiine Gobies: Biodiversity, Life Straits and Conservation. Sociètè Française d'ichthyologie.

Kottelat M, Whitten T, Kartikasari SN, Wirjoatmodjo S. 1993. Freshwater Fishes of Western Indonesia and Sulawesi. Periplus Edition, EMDI Project. Singapore, printed in Indonesia. 293p, 84 pls.

Kottelat M. 2013. The fishes of the inland waters of southeast Asia: A catalogue and core bibliography of the fishes known to occur in freshwaters, mangroves and estuaries. The Raffless Bulletin of Zoology, supplement no. 27. $663 \mathrm{p}$.

Larson HK, Geiger MF, Hadiaty RK, Herder F. 2014. Mugilogobius hitam, a new species of freshwater goby (Teleostei: Gobioidei: Gobiidae) from Lake Towuti, Central Sulawesi, Indonesia. Raffles Bulletin of Zoology 62: 718-725.

Perugia A. 1893. Sopra aleuni Pesci di Engano raccolti dal Dott. Elio Modigliani. Annali del Museo Civico di Storia Naturale di Genova, 13 (2): 251-255.

Ng HH; Wirjoatmodjo S, Hadiaty RK. 2001a. Mystus punctifer, a new species of bagrid catfish (Teleostei: Siluriformes) from northern Sumatra. The Raffles Bulletin of Zoology, 49(2): 355-358.

Ng HH, Wirjoatmodjo S, Hadiaty RK. 2001b. Hemibagrus caveatus, a new species of bagrid catfish (Teleostei: Siluriformes) from northern Sumatra. The Raffles Bulletin of Zoology, 49(2): 359-361.

Ng HH, Wirjoatmodjo S, Hadiaty RK. 2004. Kryptopterus piperatus, a new species of silurid catfish (Teleostei: Siluriformes) from northern Sumatra. Ichthyological Exploration of Freshwaters, 15(1): 91-95

$\mathrm{Ng} \mathrm{HH}$, Hadiaty RK. 2005. Two new bagrid catfishes (Teleostei: Bagridae) from Alas River drainage, Northern Sumatra. Ichthyological Exploration of Freshwaters, 16 (1): 83-92.

Ng HH, Hadiaty RK. 2008. Glyptothorax plectilis, a new species of hillstream catfish from northern Sumatra (Teleostei: Sisori- dae). Proceedings of the Academy of $\mathrm{Na}$ tural Sciences of Philadelphia 157: 137147.

Ng HH, Hadiaty RK. 2009a. Glyptothorax ketambe, a new catfish from northern $\mathrm{Su}-$ matra (Teleostei: Sisoridae). Zootaxa 2085: 61-68.

Ng HH, Hadiaty RK. 2009b. Ompok brevirictus, a new catfish (Teleostei: Siluridae) from Sumatra. Zootaxa 2232: 50-60.

Ng HH, Hadiaty RK. 2011. Clarias microspillus, a new walking catfish (Teleostei: Clariidae) from northern Sumatra, Indonesia. Journal of Threatened Taxa, 3(3): 15771584.

$\mathrm{Ng} \mathrm{HH}$, Hadiaty RK, Lundberg JG, Luckenbill KR. 2015. A new genus and species of bagrid catfish from northern Sumatra (Siluriformes: Bagridae). Proceeding of the Academy of Natural Science of Philadelphia, August 2015: 149-157.

Nielsen JG, Schwarzhans W, Hadiaty RK. 2009. A blind, new species of Diancistrus (Teleostei, Bythitidae) from three caves on Muna Island, southeast of Sulawesi, Indonesia. Cybium, 33(3): 241-245.

Parenti LR, Hadiaty RK. 2010. A new, remarkably colorful, small ricefish of the genus Oryzias (Beloniformes, Adryanichthyidae) from Sulawesi, Indonesia. Copeia 2010, 2: 268-273.

Salas LA, Bedos A, Deharveng L, Fryer S, Hadiaty RK, Heryanto, Munandar, Nardiyono, Noerdjito M, Noerdjito W, Rahmadi C, Riyanto A, Rofik A, Ruskamdi A, Struebig MJ , Suhardjono Y, Suyanto A, Vermeulen JJ, Walck C, Wiriadinata $\mathrm{H}$, Meijaard E, Stanley E. 2005. Biodiversity, endemism and the conservation of limestone karsts in the Sangkulirang Peninsula, Borneo. Biodiversity, 6(2): 15-23.

Voris HK. 2000. Maps of Pleistocene sea levels in Southeast Asia: shorelines, river systems and time durations. Journal of Biogeography, 27 (5): 1153-1167

http://news.kkp.go.id/index.php/indonesia-laporkan-16-056-pulau-bernama-ke-pbb/, diakses tanggal 17 September 2017 